\title{
Contemporary Oriental Studies on the Character of the Prophet of Islam, Our Master Muhammad (Peace Be Upon Him) and Its Impact on Western Society: An Analytical Study
}

\author{
Allaith Saleh Otoom ${ }^{1}$ \& Khalil Abd Alhameed Alabadee ${ }^{1}$ \\ ${ }^{1}$ Faculty of Calling and Foundations of Religion, The World Islamic Sciences and Education University \\ Correspondence: Allaith Otoom. E-mail: laithotoom89@yahoo.com
}

Received: May 2, 2019 Accepted: June 17, $2019 \quad$ Online Published: June 30, 2019

doi:10.5539/ass.v15n7p160 URL: https://doi.org/10.5539/ass.v15n7p160

\begin{abstract}
This study discusses the orientalist' view of the character of Master Muhammad (peace be upon him). The purpose of the study is to present and analyze the fair statements as well as presenting and analyzing the unfair statements given by orientalists. The problem of the study represents the way how the views of the orientalists and their writings are presented, showing the true image of the Prophet Muhammad (peace be upon him). Also, it refutes the suspicions undertaken by the orientalists in order to distort the image of enlightened Islam by distorting the image of the Prophet Muhammad (peace be upon him). Furthermore, few studies have been discussed this issue. The analytical approach has been used. The study concludes that the enemies of Islam have one goal which is to distort the image of Islam and its Prophet (peace be upon him) despite the differences of their means. This distorted image of Master Muhammad (peace be upon him) appeared because of the hatred filling the hearts of orientalists, depending on weak false texts of Muslims' writers. Further studies and recommendations are presented accordingly.
\end{abstract}

Keywords: Prophet Muhammad (peace be upon him), Islam, orientalists, western society

\section{Introduction}

The personality of Master Muhammad (peace be upon him) has been focused by a number of scholars. His precious personality carries dignified qualities, which cannot be denied by the author of the Book of the Great One hundred ones, placing Muhammad peace be upon him at the top of those hundred ones (Hart, 1992).

In this respect, there are many orientalists who view the character of Master Muhammad (peace be upon him) as a fair view. Others, however, have a considerable hatred of Islam. Those who have this negative view have raised suspicions to question his person. They were unfair in their words and reports. Thus, one may ask what orientalism and orientalists are.

Said (2003) defined orientalism as the "scientific discipline" which addresses the material and spiritual culture of the East in addition to the languages and history of the region. The orientalist, according to the author, is a person that deals with the science of studying the East. In this respect, the orientalist's main interest involves the understanding of the culture, philosophy and religious life of the Eastern people. Thus, orientalism is 'a western style for dominating, restructuring and having authority over the Orient' (Said, 2003, p. 48). This encompasses the study of Islam as part of the (East) orient. Today's, scholars try to construct bridges that shows an expanding climate of openness and mutual respect to understand various faiths. Moreover, a strong tendency to study Islam among some orientalists has been noted. Such orientalists have the aim not to distort and recast Islam (Varisco, 2017).

In this paper, the researchers are presenting this subject to give answers to these skeptics. It is also presented in order to show the truth of his personality, peace be upon him, in Western societies that did not know Master Muhammad (peace be upon him). Such societies knew Master Muhammad through the writings of their people without going back to the references of Muslims and without making scrutiny to reach the truth. Hence, it is important to note that the orientalists' writings must be highlighted since some of those orientalists did not pay attention to the terms of scientific research. This may occur due to their hatred of Islam and their negative talk about Master Muhammad (peace be upon him). They also described him with bad qualities as their ancestors did. 


\subsection{The Significance of the Study}

The current study focuses on the character of Master Muhammad (peace be upon him). His character has attracted the attention of many scholars due to the fact that he is the seal of the prophets and messengers and the mercy of the world.

It is necessary to have an analytical study to those researchers writing, especially if they are orientalists to show their sincerity or lies towards what they described Master Muhammad peace be upon him. Thus, describing him with inappropriate description is a challenge to Allah Almighty who chose him over the worlds. It is a challenge to the Islamic religion as well.

\subsection{The Objectives of the Study}

This study aims at determining the following:

1- To explain the concept of Orientalism.

2- To investigate the orientalists' fair view towards the character of Master Muhammad peace be upon him.

3- To analyze the orientalists' fair view towards the character of Master Muhammad peace be upon him.

4- To analyze the orientalists' unjust view of the character of Master Muhammad peace be upon him.

Limitation of the Study:

This study is limited to the statement of orientalists' view towards the character of Master Muhammad peace be upon him. The current study does not expose to orientalists' view towards other issues such as their views towards the Holy Quran, the Sunnah, or the revelation. It is also confined to the orientalists' view in the past two centuries.

\section{Literature Review}

The related literature will discuss the overview of this paper's issue and present the views of the orientalists towards the character of Master Muhammad.

\subsection{Overview of the Issue}

The efforts of the orientalists and the enemies of religion have continued to appear from time to time to distort the image of the Master of the messengers. As the images and films began to be more wanted by the people, the enemies of Islam went to use them in their war against Islam. This made a multitude of people draw in their minds the image of the Master of the messengers as a bloody, lustful person, depending on the orientalists' unjust writing. Al-Zoubi (2013) stated that a number of orientalists in later times succeed in influencing the minds of some Muslims. Hence, they were deceived by their writings and studies on Islam on the belief that their studies were based on subjectivity, fairness, and neutrality. Then, they were traced and followed their call that did not have any proof. They shed their poison in the name of scientific research, knowledge and freedom of criticism. The author confirmed that they were actually far from the right science, fair research and criticism.

Therefore, it is necessary to show the correct bright image of Master Muhammad peace be upon him not only relying on the writings of Muslims but also paying attention to the writings of orientalists whose working and writings formed references used by the Western consciousness in crystallizing the perception of Islam and his prophet. Thus, there is an urgent need to analyze such works and writings (Fazio, 2011).

\subsection{Overview of the Dispute}

Recently, the war on Islam has been renewed. At this stage, the focus has been on distorting the image of Master Muhammad (peace be upon him) in order to present it to the Western world in a bad way. This bad image probably prevents the West from accepting Islam and leads to extinguish the light of Islam. Thus, the West is aware of the importance of learning about the life of Master Muhammad (peace be upon him). Regarding the importance of this issue, Boisard (1987) pointed out that having a look on his life is necessary due to the strong relationship between the message and the messenger. It is important to note that the Holy Quran urge not only to the human nature of the prophet, but the Holy Quran makes him a best model that should be followed by believers.

\subsubsection{The Orientalists' Fair View Towards the Character of Master Muhammad (Peace Be Upon Him)}

There are a number of orientalists' writings and their views on the character of Master Muhammad (peace be upon him). Some of these writings were characterized as being objective and having scientific honesty. This leads to a fair view of Master Muhammad's character. Carlyle (2017) mentioned some of the character of Master Muhammad (peace be upon him). The author stated that Master Muhammad has been observed throughout his 
life as man who has a firmly established principle, resolute determination, carefree, in addition to being generous, pure, free, easy going, and strict honest. Overall, his face is filled with a light and bright smile of honest heart.

In the same context, the same author also stated that it was observed from the time of his youth that he was a young thinker, and his faithful companions called him a man of honesty and loyalty; a man who is described as honest in his actions, words and ideas (Carlyle, 2017). In addition, Carlyle (2017) gave a description to the character of the Prophet (peace be upon him) as being evidenced in the prophet's perfumed biography, which has been the clearest biography of a man throughout history. However, there are those who cover this truth, forgetting that he is a man of honesty and loyalty and they began to give a negative view for his character. This will be discussed in the next section.

Under the title of "Who was Mohammed?" Qubayn (2014) stated in his book that the orientalist Liotlstoy confirmed that Muhammad is the founder and apostle of the Islamic religion, which is followed and believed throughout the world by 200 million followers. The Prophet Muhammad has been one of the greatest of the reformers who has served the social service. The author also stated that Master Muhammad guides an entire nation to the light of truth, making it leaned towards tranquility and peace as well as preferring the existence of asceticism, preventing the bloodshed, and opening the way of advancement and civilization. This is a great work done only by a powerful person who has worthy of respect and honor.

Nowadays, some orientalists replace the previous statement "guides an entire nation to the light of truth, making it leaning towards tranquility and peace as well as preferring the existence of asceticism, preventing the bloodshed" with the statement that is being described as a bloody man carrying arms in his hands.

As for the fair view of the orientalists, Zaiter (1969) pointed out in his book that the orientalist Gustav Le Bon noted that some Western scholars offer fair and just views about the character of Master Muhammad even though religious fanaticism has blinded many historians to the recognition of his virtue. It is important to note that one of the statements the author mentioned is that Muhammad received great fame, was known with his kindness and sincerity. For these reasons, his tribe-Quresh- called him as sincere. His tribe has been considered as a fierce enemy to him for twenty years. However, Master Muhammad dealt his tribe with kindness and patience. Thus, if the value of men was measured by their works, Muhammad was one of the greatest in history (Zaiter, 1969).

Another author offered fair view towards Prophet Muhammad. This author is Dr. Michael Hart who defended his opinion after putting the character of Muhammad at the top of the 100 tops. Dr. Michael Hart is the author of the book "The 100". For example, Mohammed Al-Shaibani pointed out that some orientalists provided fair views to the Prophet (Peace be upon him and gave him some of his right, represented the spirit of Islam, and objectively realized the historical importance of the prophet away from the positions of fanaticism. One of those fair orientalists who stand in the forefront is Dr. Michael Hart who is the author of the book "The 100". His book classified the greats of history within an ordinal hierarchy. It was chosen according to logical standards, depending on the effect of this character in history in its stage and in shaping the trends of the following stages as well as the sustainability of this effect (Al-Shaibani, 1988).

It is crucial to note that Dr. Michael Hart stated that the choice of Muhammad to be the first in the list of the most important men in history may have surprised many readers to the extent that it might raise some questions. He also believed that Muhammad (Peace be upon him) was the only man in history who prominently and highly succeeded in both the religious and worldly levels (Hart, 1992).

Furthermore, the author of the book, entitled "Humanism in Islam" under the title of the Seal of Prophets, stated that everything has already been written about the Prophet of Islam. The lights of history have dominated his life, that one knows in the most accurate details as well as the image left by Muhammad (peace be upon him) even though that image has been deliberately distorted (Boisard, 1987)

Based on the aforementioned, some of the orientalists' writings gave a fair view about the character of Master Muhammad (peace be upon him) and there are more writers who wrote fair writings that were not mentioned in this paper (Al-Shaibani, 1988).

\subsubsection{The Orientalists' Unfair View Towards the Character of Master Muhammad (Peace Be Upon Him)}

Despite the existence of many fair writings regarding Master Muhammad (peace be upon him), one can find from time to time those who claims otherwise. Such authors did not have objectivity in their writings concerning the Prophet Muhammad (peace be upon him). As for the reason for such view lacking objectivity, some scholars relate it to hatred and hostility. Al-Zoubi (2013) pointed out that the motive that prompted those orientalists to study Islam is in fact the blatant hostility to this religion and to the Prophet Muhammad (peace be upon him). He also stressed that such hostility started from the beginning of Islam. He added that the orientalists are only an 
extension of some extremists of other religions who did everything to obliterate the religion of Islam as well as removing its features from existence. This hostility was not decreased by successive centuries. Rather, it took various images and forms; such images were obviously shown and sometimes disguised.

Additionally, the same author stated that their prejudice to the Prophet Muhammad (peace be upon him) is considered as a response to the call of the Crusaders inherited from their parents, characterizing him with ugly qualities (Al-Zoubi, 2013).

In the same thread, Khalil (2005) confirmed that the western attitude towards the Messenger of Islam Muhammad (peace be upon him) is purely formed in a religious framework in a way that is full of fanaticism and emotion which is full of anger and hatred surrounded by blind ignorance. This made a wall that is difficult to penetrate between the people and the character of Prophet Muhammad peace be upon him. Such result was not based on historical scientific research lacking objectivity. However, it was characterized as insults practiced by clerics from the heart of the Christian Church and secular men having no relation to the Church. The author added that this trend has continued until this time.

In the same context, Fazio (2011) asserted that it was natural that the Christian version of the Prophet formed a dark image for which all the historical information was gathered. This stereotypical view can be summed up in three basic pillars: the sensuality of the Prophet, his claimed prophecy, and his resort to violence in order to achieve his political project.

As for the charges mentioned above that have attached to the Prophet Muhammad peace be upon him, the researchers will introduce them providing the suitable response. For example, Abu Shahba (2006) stated that what helps to accept their views is that some educated people, especially who did not get Islamic culture and authentic Islam in a way that qualified them to distinguish between right and wrong, viewed orientalists as being the top in thinking and in research. Thus, they did not review and deny what they said. Moreover, some of those were educated with Islamic culture had slipped and translated some of books without commenting what is wrong and what is right.

Consequently, the question one can pose is that why such writers did not pay attention to orientalists who wrote fair writings about Islam and his Prophet Muhammad (peace be upon him). It is important to note that the orientalist Drumming (2013) pointed out in his book that when the war broke out between Islam and Christianity in many centuries, the misunderstanding between the two religions intensified. He added that one should admit that the Westerners were the first who caused this dispute. Some men of the Byzantines also underestimated and despised Islam without studying it appropriately.

Thus, if this unfair view is due to lack of study of the character of Master Muhammad (peace be upon him), this research provides a study for this particular purpose. One may find a fair view of his character through the responses to those orientalists who were unfair in their ugly description of Master Muhammad (peace be upon him) in which it reflected negatively on his ethics and his character.

Additionally, it is worth mentioning that there are orientalists who studied the Prophet of Islam, Master Muhammad (peace be upon him). However, their studies are destined for the search for narratives that serve their purposes in challenging Islam and its Prophet. Concerning those studies, Abu Shahba (2006) pointed out that a large number of the orientalists of every race and color wrote books about the biography of the Prophet of Islam. Few of these orientalists had fair views and many of them had unfair views. Generally, most of the orientalists have preached their religions, carrying hatred of Islam and the Prophet of Islam. The author added that such orientalists search for a gap to spill out their hatreds and poisons. They fabricated the truth as long as it helps them in achieving their desires. They hid under the cover of scientific research and freedom of opinion in order to dissolve the bonds of faith from the souls of Muslims as well as questioning the biography of their ideal, the Prophet of Islam (peace be upon him).

On the other hand, there are those who wrote something not mentioned in orientalists' books. For example, they wrote about the orientalist Lubon in a way that he claimed the absence of the personality of the Prophet Muhammad (peace be upon him). Almahjoubi (2010) asserted that when they researched and studied the character of the Prophet Muhammad (Peace be upon him), they came with views and surprising words. Some orientalists questioned the existence of his character (peace be upon him), making him a fictional figure that did not exist in reality. One of those orientalists was the Russian orientalist (Tolstof). This orientalist contrasted with the majority of orientalists who admitted the prophet's existence (Al-Mahjoubi, 2010). Such claim is not true; Qubayn (2014) translated one of Tolstoy's books entitled "The Rule of the Prophet Muhammad" and the existence of the character of the Prophet Muhammad (peace be upon him) was proved. 
Such slander on Master Muhammad (peace be upon him) came to be apparent to several orientalists. Watt (1974) stated that there has never been any slander against any of the great men of the world as they have denied Muhammad. In response to these charges against Master Muhammad (peace be upon him). Paret (2005) pointed out that the charge relating to his integrity or honesty against the Prophet Muhammad through ages and up to modern times can be weakened. Such charge was expressed by the discontentment on the Prophet' honesty (Paret, 2005). It is important to note this slander remained in their books and turned into portraits and films (Olesen, 2005). For example, a group of Danes, who were related to the educated class in the society, drew the image of Master Muhammad (peace be upon him) as they actually saw it through their culture and their ecclesiastical heritage extended deeply in history. An image came out that is almost to be identical to what the medieval European thought of the Prophet; such image can describe Master Muhammad as a violent bloody terrorist person who exploits women to satisfy his will (Zermann, 2012).

\subsection{Questioning the Character of the Prophet Muhammad (Peace Be Upon Him)}

Questioning the character of Master Muhammad took several forms. These forms include the following:

1-Carring the sword is a reference to his brutality and his bloody personality

One of the unfair views towards Master Muhammad (peace be upon him) is the view that described him as the bloody person who carries the sword. Mousa (1963) confirmed that this charge is clearly evident in their offensive drawings, which came in the writings of orientalists like Ignatz Goldzier. This person described the Prophet of Islam as the one who carries the sword in the world and does not suffice with his stick that hits the ground. It is the sword of the war that was blowing in it; the bloody sword he raised for the establishment of his kingdom. In a consecutive Islamic narrative, his mission was shown in a way that he bore the title mentioned in the Torah. This title represents the Prophet of fighting and war (Mousa, 1963). Thus, having a look at the Torah, we will not find the above description will not be found (Tahtawi, 1972).

It is crucial to indicate that in his translated book Mousa (1963) pointed out that Ignatz Goldzier later contradicted himself by describing Master Muhammad as a Prophet of mercy and love. The author stated that this orientalist himself, Ignatz Goldzier, confirmed that if one wants to be fair to Islam, he/she agrees that there is an effective power in its teachings directed towards good. In addition, according to the teachings of this power, life can be a good life full of morality. These teachings require the mercy of all creations of God, honesty in people's relations with each other, love and sincerity, as well as suppressing the instincts. Also, they require the virtues Islam took from previous religions in which Muhammad recognizes the prophets as his teachers. As a result, the good Muslim lives a life that is commensurate with the most precise morality (Mousa, 1963). Consequently, the question one can pose is that: Should the one, who calls for the teachings that require the mercy of all creations of God, be the Prophet of fighting and the sword?

A response to such claim which is the Prophet of fighting and the sword, Al- Ghazali (2005) replied that it is a slanderous phrase and a poisonous expression. He added that Master Muhammad did not establish a kingdom for himself. The prophet himself established a valuable religion for God. He was able to establish his pillars with a wealth of bitter struggle against two kingdoms that filled the world with ignorance and tyranny. The orientalists felt sad concerning the king of the Persians or the king of the Romans. The author wonders whether they dare to claim that these vast empires were a cemetery for certainty, freedom, and justice. He added that the salvation of the world from those kingdoms was a good thing made by Islam (Al- Ghazali, 2005).

In the same thread, Carlyle's (2017) response to this alleged slander can be summarized as much has been said about the spread of Muhammad's religion by the sword. If some people made slander a proof of his lie, they committed a sin. They thought that religion would not spread without the sword. The author pointed out that it is not the sword but the power of the religion which is right.

He also explained his opinion on this issue through the religious texts that order justice, charity, and the call to God using wisdom and good exhortation. In addition, he pointed out that Muhammad's intention has so far been to spread his religion using only wisdom and good advice. When Muhammad found that the wrongdoing people rejected his divine message and did not listen to the voice of his conscience and heart, they wanted to silence him in order not talk about his message. Thus, as the son of the desert, he intended to defend himself (Carlyle, 2017).

Additionally, some orientalists who clung on to the application of the rule of God in Bani Quraizah tribe regarding that claim, described Islam and Prophet (peace be upon him) as intensity and having the tendency to shed blood. However, the reader and researcher for the provisions of Islam in that period find that the application of God's rule issued by the law of war. It is important to indicate that Bani Quraizah tribe lived in Madinah. This place included the Islamic state. It was actually a fighting place, surrounded by enemies everywhere. The most 
serious enemies were the internal enemies who grew up in the heart of Madinah. Because of this state of war which was in Madinah at that time, the legal provisions cannot be applied. Instead, exceptional provisions taken from the law of war can be applied (Alfares, 2011).

Consequently, there is no reason for their objections to what the Islamic law has come such as the killing of the disbelievers, the aggressors, the oppressors and those who annulled the covenants. It is important to note that the privilege of Islamic forbids the killing of women, boys and monks.

Finally, based on the above responses, this slander continues to occupy the forefront in the field of media warfare. This kind of media aims to distort the image of Islam in the past and the present. Its promotion was an important introduction in urging the European peoples to launch the Crusades against the Islamic world. In these contemporary times, many television programs and films specialized in the dissemination and promotion of this rumor. Unfortunately, Islam is mentioned in conjunction with violence and terrorism (Kemal, 1970).

\section{2- Sensuality}

One of the unfair views called by the orientalists is the sensuality of the Prophet Muhammad (Peace be upon him). Concerning this particular view, Fazio stated that the medieval Christian narrative emphasizes the sensuality of the Prophet. To prove such slander, the narrative depended on the marriage of the Prophet mentioned in books of his biography. It also depicts his religion in the images of women and sex. As for his religion, it was not only a value of life but also a component of his vision for the paradise in the life after death (AlSabateen, 2010).

It should be noted that one of the orientalists, who has the fair view regarding the past slander which is being bloody person carrying a sword, repeatedly mentioned the sensuality of Master Prophet Muhammad, peace be upon him. This orientalist is called Lubon. In his book, Zaiter, 1969) noted that Lubon pointed out that Muhammad's only weakness was his urgent love for women. The author added that Lubon stated that Muhammad did not care about the age of the woman he married. For example, Muhammad married Aisha when she was ten years old and married Maymouna, who was 51 years old. He loved both of them. It was agreed that Muhammad saw Zainab (the wife of his adopted son) naked and he liked her. His son divorced her in order to let Muhammad marry her. For that incident, Muslims did not like what happened. The divine inspiration represented by Jibril who communicated daily with the Prophet revealed verses justifying that incident. Thus, the criticism turned into silence (Zaiter, 1969).

The researchers inquired about Lubon's source concerning the agreement on the Prophet's view to Zainab naked! Moreover, Mousa (1963) confirmed in his book that Ignatz Goldzier mentioned this slander and challenge it by questioning the character of Master Muhammad (Peace be upon him). He added that this orientalist, Ignatz Goldzier, stated that those narratives also make him in a position to be accused by his opponents who pointed out that he has nothing to do but women and this does not conform to the characteristic of prophecy (Mousa, 1963).

To manifest the story of the marriage of Prophet Muhammad (Peace be upon him) mentioned by Dermenghem (2013), this author reported that Muhammad entered the house of Zaid Ibn Haritha-his adopted son- one day after the conquest of Bani al-Nadir. Muhammad loved Zaid Ibn Haritha very much. Therefore, he adopted Zaid and he was known as Zaid Ibn Muhammad. The Prophet Muhammad consulted him in every matter. One day, Zaid was absent from his home. Muhammad found himself against Zainab Bint Jahsh, the wife of Zaid, who was one of the most beautiful women in the tribe. Zainab did not wear Hijab and was semi-naked and was working on her adornment and house-keeping. This pure beauty affected the self of the Prophet by saying (Almighty who can change everything) and he did not utter but this phrase. Then, the same orientalist ended his story by saying that when the period of Zainab passed away in order to marry another one after divorce. She told Muhammad the divorce and sent to him someone who said to him that Zaid divorced me for your sake. Muhammad was interested in marrying Zainab, but he was shy and knew that the Sharia (law of Islam) forbade the marriage of the father to his adopted son's wife in the same way that forbade the marriage of the father to his real son's wife. God knows what confused Safeyah (mother of Zainab) and the Prophet married Zainab since he inspired him to do so among Angels (Dermenghem, 2013).

It is important to note that this research paper can have these responses to this slander as following: Firstly, the Prophet's enemies and friends have known him as being honest in speech and action. Secondly, those who see the reality of the Prophet (peace be upon him) and his condition of asceticism as well as abandoning the pleasures of life extremely realize that such slanders are not true. Thirdly, if the man who is lustful reaches an authority just like the Prophet (peace be upon him) does, it is not difficult for that man to gather the most beautiful girls of the Arabs and Persia. The Prophet does not do that action (Akkad, 2013). Fourthly, it is not difficult for him to provide himself and his family with food, clothes and adornment unless this provision is 
available to the masters of the peninsula in their times. Again, the Prophet does not do this action but the opposite; the biography witnesses the honesty of the prophet (Akkad, 2013). Fifth, if the Prophet wants sex and desire, he will choose the young women without choosing the old women. The Prophet does not do such action. Sixth, the lustful man does not reach the age of twenty-five in the environment of the Arabs in its ignorant stage without being dragged into the current corruption. The Prophet's peers witness his chastity and honor (Amin, 2013).

Another response came from Ayaad (2002) who explained the story of the Prophet's marriage to Zainab through the events of the biography mentioned in the holy Koran in Al-Ahzab (verse: 37) The most correct interpretation narrated by Ali Bin Hussein is that God told his prophet that Zaynab will be one of his wives. When Zaid complained to the Prophet, the Prophet told him that he should keep his wife without divorcing her and should fear God. The prophet hid what God told him that he himself would marry Zainab after Zaid divorce her. God told his prophet to let Zaid divorce his wife and let the prophet married her after his adopted son's divorce. God made this action to prohibit and invalidate the adoption (Ayaad, 2002).

\subsection{Related Studies}

There are few studies that discussed the character of Master Muhammad (Peace be upon him). These studies include the following:

1- Hamdan (2013) conducted a book entitled "The Prophet (peace be upon him) in the writings of orientalists". It differs from this study in that the writer dominated the aspect of the call to Allah (God) without focusing on the aspect of scientific research. For example, in his book, the author mentioned the orientalist's statement without showing the reference. He just mentioned the suspicion of the orientalist's words and then began to give a response to his claim. This book was written more than 35 years ago. Thus, it was not exposed to the subsequent writings, images, and films insulted to Master Muhammad (peace be upon him).

2- Alzoubi (2006) conducted a study tackling the scientific character of the Prophet Muhammad (peace be upon him). His study only dealt with the scientific aspect of the life of Master Muhammad (peace be upon him). However, this research paper includes the orientalists' view towards the character of Master Muhammad (peace be upon him) in general.

3- In 1992, Al-Hussain conducted a research paper entitled "The Position of the Orientalist, Seydou, towards the Biography of the Prophet - A Critical Study". In his paper, the researcher was limited to one orientalist to discuss and talk about the Prophet's biography.

4- Habashneh (2014) conducted a study entitled "Muhammad, peace be upon him, in the Literature of the Middle Ages and its Impact on Montgomery Wat". The researcher highlighted the light on one orientalist and mentioned some of those who were influenced. His study focused on the literature in the middle ages. However, this current paper addresses the issue raised nowadays even though it has previous roots.

\section{The Methodology of the Study}

The analytical method will be used by the researchers by collecting the orientalists' statements concerning the character of Master Muhammad (peace be upon him). After collecting the data, the researchers will discuss, analyze, and then criticize them to show the truth and untruth of the statements.

\section{Conclusion of the Study}

This study can be concluded as follows:

First, the enemies of Islam have one goal that is to distort the image of Islam and its Prophet (peace be upon him) though their means are different. Second, this distorted image of Master Muhammad (peace be upon him) came through the hatred that fills the hearts of some orientalists as well as relying on weak false narratives existing in the books of Muslims' writers. Third, their results of the distortion of the image of Master Muhammad (peace be upon him) were contrary to what they wanted in a way that the West recognized the Prophet of Islam and the entry of many of the West in the religion of Islam. Fourth, there are contradictions in the writings of some of the orientalists (Badawi, 1993). Also, one can find books that are not translated in a way that makes it even harder in that aspect.

\section{Recommendations of the Study}

The researchers recommend the following aspects. First, one should not rely on the writings of some of the orientalists regarding any religious issue. Second, efforts should be intensified in studying and translating orientalists' books in order to show the untruth, misguidance, and its reality for the Arabs and the West as well. Third, the use of modern means to present Islam and its Prophet (peace be upon him) in the right image they 
deserve.

\section{Acknowledgments}

The researchers are thankful to the Faculty of Calling and Foundations of Religion at the World Islamic Sciences and Education University.

\section{References}

Abu Shahba, M. (2006). Biography of the prophet in the light of the Quran and Sunnah (8th ed.). Dar Al-Qalam, Damascus.

Alfares, B. (2011, December 22). The slaughter of Bani Quraiza. Civilized Dialogue. Retrieved from http://www.ahewar.org/debat/show.art.asp?aid=288366

Alhussain, S. (1992). The position of the orientalist, Seydou, towards the Prophet's Biography (Master Thesis, Riyadh, Imam Muhammad Bin Saud University).

Al-Askalani, A. (2001). Fath al-Bari- Sharh Saheeh al-Bukhari. Modern Library, Beirut. Hadith No. 3533.

Al- Ghazali, M. (2005). Defending the doctrine and the Sharia against the slander of the orientalists. Nahdet Misr for Printing and Publishing. Egypt.

Al-Mahjoubi, K. (2010). Orientalism and Islam. Academy of Public Thought, Libya

AlSabateen, R. (2010). Suspicions and slander of religious orientalism in the face of Islam and the prophecy of Muhammad (peace be upon him). Alukah net, Amman, Jordan.

Al-Shaibani, M. (1988). The prophet in the fair oriental studies. Arab Civilization House Beirut, Lebanon.

Alzoubi, M. (2006). The scientific character of Prophet Muhammad. The Journal of the University of Isfahan, (3) 445.

Al- Zoubi, M. (2013). The scientific character of the prophet (peace be upon him). Amwaj for Publication and Distribution. Jordan.

Al-Shaibani, M. (1988). The prophet in the fair oriental studies. Arab Civilization House Beirut, Lebanon.

Akkad, A. (2013). The facts of Islam and the falsehood of its opponents. Hindawi Foundation for Education and Culture. Egypt.

Amin, S. (2013). The fabricated slanders and lies against the prophets and Islamic and historical figures. Sientific Sawaki House. Amman, Jordan.

Ayyad, Q. (2002). Al-Shifa in defining the rights of Mustafa. Dar al-Fikr. Lebanon.

Badawi, A. (1993). Encyclopedia of orientalists. Darul Elm for Millions. Lebanon.

Boisard, M. (1987). Humanism in Islam. Amer Trust Pubns, Paris.

Carlyle, T. (2017). On heroes, hero-worship, and the heroic in history. HardPress. FL. USA. https://doi.org/10.1515/9783110516678-007

Dermenghem, E. (2013). The Life of Mahomet. Literary Licensing, LLC.USA.

Edward Said, E. (2003). Orientalism. Penguin Group, London.

Fazio, N. (2011). The imagined Messenger-A critical reading of the image of the prophet in Orientalism. Forum knowledge, Lebanon.

Habashneh, B. (2014). Muhammad, peace be upon him in the Literature of the Middle Ages and its Impact on Montgomery Watt. The Jordanian Journal of Islamic Studies, 4(5).

Hamdan, N. (2013). The Prophet (peace be upon him) in the writings of orientalists. World Islamic Association Print. Egypt.

Hart, M. (1992). The 100: A Ranking of the most influential persons in history. Citadel Press NY.

Kemal, M. (1970). Muhammad and the Sons of Israel. Supreme Council for Islamic Affairs. Ahram Press. Cairo, Egypt.

Khalil, E. (2005). Orientals and the prophet's biography (1st ed.). Dar Ibn Katheer for Printing, Publishing and Distribution, Damascus, Beirut, Lebanon.

Mousa, M. (1963). The doctrine and sharia in Islam (A Translated edition). Modern Book House. Egypt. 
Olesen, S. (2005, September 30). The face of Muhammad. The Danish newspaper Jyllands-Posten. Retrieved from http://www.atour.com/news/international/20101211a.html

Paret, R. (2005). Mohammed und der Koran. Kohlhammer W. Germany.

Qubayn, S. (2014). Leo Tolstoy: The rule of Prophet Muhammad: A translation. Hendawi Foundation for Education and Culture. Egypt.

Tahtawi, M. (1972). Muhammad the prophet of Islam in the Torah, the Bible, and the Qur'an. Altaqudum Print, Egypt.

Varisco, D. (2017). Orientalism and Islam. Retrieved from http://www.oxfordbibliographies.com/view/ document/obo-9780195390155/obo-9780195390155-0058.xml

Watt, W. (1974). Muhammad: Prophet and statesman. Oxford University Press. London.

Zaiter, A. (1969). The civilization of the Arabs. A translation. The Library of Iman. Isa Al-Babi Al-Halabi \& Co. Press. Egypt.

Zermann, M. (2012). The prophet in western thought between fairness and unfairness. Media House, Jordan.

\section{Copyrights}

Copyright for this article is retained by the author(s), with first publication rights granted to the journal.

This is an open-access article distributed under the terms and conditions of the Creative Commons Attribution license (http://creativecommons.org/licenses/by/4.0/). 